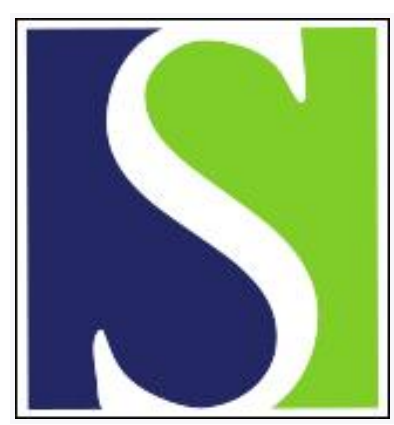

Scand J Work Environ Health 1977;3(4):225-233

https://doi.org/10.5271/sjweh.2770

Issue date: Dec 1977

Age and sex as determinants of the relative aerobic strain of nonmotorized mail delivery.

by Oja P, Louhevaara V, Korhonen 0

Key terms: aerobic strain; age; elderly worker; female worker; gender; mail delivery; nonmotorized mail delivery; relative aerobic strain; sex

This article in PubMed: www.ncbi.nlm.nih.gov/pubmed/594730

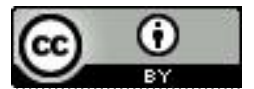




\title{
Age and sex as determinants of the relative aerobic strain of nonmotorized mail delivery
}

\author{
by PEKKA OJA, Ph.D., VEIKKO LOUHEVAARA, M.Sc., \\ and OLLI KORHONEN, M.D. ${ }^{1}$
}

\begin{abstract}
OJA, P., LOUHEVAARA, V. and KORHONEN, O. Age and sex as determinants of the relative aerobic strain of nonmotorized mail delivery. Scand. $j$. work environ. \& health 3 (1977) 225-233. The relative aerobic strain (RAS) of nonmotorized mail delivery was assessed in 54 Finnish mail carriers who represented both sexes, the entire workage range and both downtown and suburban delivery districts. The mean RAS of the entire delivery time was $55 \%$ of the maximal oxygen uptake $(\mathrm{ml} / \mathrm{kg}$. $\mathrm{min})$. It was higher for women than for men, and higher for suburban than for downtown delivery. The RAS tended to increase systematically with age after the age of 50. The work strain of mail carriers of over 50 years of age, especially of older women carriers in suburban areas, was concluded to be high enough to lead to possible excessive strain on the workers.
\end{abstract}

Key words: aerobic strain, elderly workers, female workers, mail delivery.

Finnish mail carriers usually deliver the mail in urban areas on foot or by bicycle. In downtown business districts they work mainly on foot and carry the traditional shoulder bag, which holds approximately $15 \mathrm{~kg}$ of mail when full. In suburban districts the carriers generally use a bicycle during delivery, but they have intermittent on-foot phases when the bike cannot be ridden. A bicycle carrier normally keeps the shoulder bag on a front rack, where it is easily accessable. Additional mail is carried in bags on the back of the bike. In both types of delivery excess mail is stored in stack boxes located along the delivery route.

In addition to delivering the mail, the task of the carriers consists of sorting the mail before the delivery. Sorting requires 1 to $3 \mathrm{~h}$ and delivery between 1.5 and $5 \mathrm{~h}$,

1 Department of Physiology, Institute of Occupational Health, Vantaa, Finland.

Reprint requests to: Dr. Pekka Oja, Institute of Occupational Health, Laajaniityntie 1, SF01620 Vantaa 62, Finland. depending on the amount of mail. The carriers receive a fixed salary with a time premium that allows them to be free as soon as the delivery has been completed.

Energy consumption values of 558 to 837 $\mathrm{W}(8-12 \mathrm{kcal} / \mathrm{min})$ have been measured for British mailmen during on-foot delivery with a full mail bag (9). The energy consumption of cycling (2) suggests roughly equal demands for bicycle delivery. Standard work classification (5) presents work stress of this magnitude as heavy or very heavy for young healthy men. Since in Finland the mail-carrying force consists of both men and women in the entire workage range and physical work capacity is known to decrease with age and is lower in women than in men, it appears that the physiological strain relative to the workers' performance capacity might be considerably high for a large part of the carriers. Consequently, the purpose of our study was to determine the relative physiological strain of mail delivery and the extent to which it is affected by the age and sex of the carriers. 
Table 1. Selection of subjects.

\begin{tabular}{|c|c|c|c|}
\hline Phase of selection & Men & Women & All \\
\hline Selected for screening & 44 & 49 & 93 \\
\hline Did not participate & 4 & 1 & 5 \\
\hline Screening examination & 40 & 48 & 88 \\
\hline Excluded & 12 & 18 & 30 \\
\hline Medical contraindications & 4 & 13 & 17 \\
\hline Other & 8 & 5 & 13 \\
\hline Selected for maximal stress test & 28 & 30 & 58 \\
\hline Did not participate & 1 & - & 1 \\
\hline Completed test & 26 & 28 & 54 \\
\hline Did not complete test & 1 & 2 & 3 \\
\hline
\end{tabular}

Table 2. Anthopometric characteristics of the subjects.

\begin{tabular}{|c|c|c|c|c|c|c|c|}
\hline \multirow{2}{*}{ Group } & \multirow{2}{*}{$\mathrm{n}$} & \multicolumn{2}{|c|}{ Age (years) } & \multicolumn{2}{|c|}{ Height $(\mathrm{cm})$} & \multicolumn{2}{|c|}{ Weight (kg) } \\
\hline & & Mean & $\mathrm{SD}$ & Mean & $\mathrm{SD}$ & Mean & $\mathrm{SD}$ \\
\hline \multicolumn{8}{|l|}{ Men } \\
\hline Suburban & 12 & 39.5 & 12.5 & 173.8 & 6.3 & 73.5 & 10.5 \\
\hline Downtown & 14 & 42.8 & 11.4 & 175.2 & 8.4 & 72.5 & 11.3 \\
\hline \multicolumn{8}{|l|}{ Women } \\
\hline Suburban & 14 & 43.0 & 13.1 & 163.0 & 5.3 & 66.3 & 10.2 \\
\hline Downtown & 14 & 41.5 & 11.8 & 162.4 & 7.1 & 59.9 & 8.4 \\
\hline
\end{tabular}

\section{MATERIAL AND METHODS}

Ninety-three mail carriers from Helsinki and its vicinity and with work experience of a minimum of two years were invited to the screening examination (table 1). This group was selected to represent evenly both sexes, suburban and downtown delivery districts, and the age groups under 35 years, $35-50$ years and over 50 years. Five of the 93 did not participate, 17 were excluded for medical reasons, and 13 were excluded randomly so that the number of subjects in the subgroups would be equal. The remaining 58 subjects were invited to a maximal stress test. Fifty-four of them completed the test successfully. These subjects were divided into 12 subgroups by age $(<35,35-50,>50$ years), sex, and delivery district (downtown, suburban) for statistical treatment by the analysis of variance. The anthropometric characteristics of the subjects are shown in table 2.

Maximal oxygen uptake $\left(\mathrm{VO}_{2}\right.$ max) was determined during a progressive uphill walk on a motor-driven treadmill. The test was started with a 5-min warm-up walk on a $5 \%$ inclination at the individually adjusted speed of 4 to $5.5 \mathrm{~km} / \mathrm{h}$.
After the warm-up the treadmill grade was increased by $2.5 \%$ every 2 min up to a maximal grade of $20 \%$. Thereafter the work load was increased by treadmill speed increments of $0.5 \mathrm{~km} / \mathrm{h}$ every $2 \mathrm{~min}$. The subjects were asked to walk to their self-determined subjective maximum. The test was discontinued prematurely whenever signs or symptoms of excessive physiological strain occurred.

During the treadmill walk, a 4-lead ECG was continuously monitored on an oscilloscope and a paper recording was made during the last $15 \mathrm{~s}$ of each minute. A $1-$ to 2 -min sample of expired air was collected through a Tripple-J breathing valve into a Douglas bag at three submaximal work loads and at the maximal work load. For the calculation of oxygen consumption the volume of expired air was measured by a dry gas meter, oxygen was analyzed with a paramagnetic $\mathrm{O}_{2}$ analyzer (Taylor Servomex OA 150) and carbon dioxide with an infrared $\mathrm{CO}_{2}$ analyzer (Datex $\mathrm{CD}$ 101). The heart rate and oxygen consumption measurements were used to establish their linear relationship for each subject in the form of a first-order regression equation. 
The heart rate of each subject was monitored telemetrically during the mail delivery. The subjects were carefully informed of the importance of working at their normal pace. A bipolar ECG signal was obtained with a portable heart rate meter (Medinik IC-600) and stored by a portable (Uher $\mathrm{Cr} 210$ ) or car-mounted (Stellavox ABR) tape recorder. The person doing the monitoring followed the subject either in a van or on foot. A predetermined code for the main phases of work was stored on the magnetic tape simultaneously with the ECG signal. The tape was further processed by an automatic data analyzer, which calculated the mean heart rate per minute for each successive 15-s period and for the period preceding the change of work phase. These data were subjected to a computer analysis that determined the mean heart rates for the entire delivery time and for each work phase.

The working heart rate was used in the estimation of oxygen consumption based on the individual heart rate/oxygen consumption regression equations as determined in the stress test. The relative aerobic strain (RAS) was calculated as

estimated work $\mathrm{O}_{2}$ consumption $(\mathrm{ml} / \mathrm{kg} \cdot \mathrm{min})$

maximal oxygen uptake $(\mathrm{ml} / \mathrm{kg} \cdot \mathrm{min})$

multiplied by 100 .

A fixed three-way analysis of variance with age (three levels), sex (two levels) and delivery district (two levels) as the three directions was employed in the analysis of the effects of age, sex and delivery district on selected variables.

The yield of the analysis of variance on each variable was examined further in the following manner: If there was a statistically significant $(\mathrm{p}<0.05)$ three-way interaction, two-way interactions were examined separately on each level of the third direction. If the three-way interaction was not significant, the overall two-way interactions were considered next. If none of the three two-way interactions were significant, the main effects yielded by the overall analysis of variance were tested. If only one of the twoway interactions was significant, the two main effects that interacted were tested separately on their different levels, and the third main effect was tested as yielded by the overall analysis of variance. In the case of two significant two-way interactions, each main effect was tested separately on the different levels of each direction. When a significant overall $\mathbf{F}$ was obtained, the Newman-Keuls procedure (7) was utilized in the follow-up test of the means if three means were involved (comparison between the three age groups). When only two means were compared, the significance of the $F$ value in the analysis of variance of main effect was used.

\section{RESULTS}

Some of the characteristics of the downtown and suburban delivery are presented in table 3 . Only the most important work phases with respect to physiological strain have been listed. For both types of delivery the mean of the measured duration of the entire delivery was somewhat shorter than the normal delivery time that had been reported by the mail carriers. This difference reflected the fact that part of the field measurements were made during the quiet summer season. In the downtown area both delivery on level surfaces by foot and delivery while coming down stairs required slightly less than $30 \%$ of the total time. Both delivery while climbing stairs and delivery by bicycle took about $10 \%$ of the total time. In suburban districts delivery by foot required about half of the time and bicycle riding about $40 \%$.

The mean maximal values of the cardiorespiratory variables for the 12 groups are shown in table 4. The decrement of $\mathrm{VO}_{2}$

Table 3. Some characteristics of downtown and suburban delivery (mean values).

\begin{tabular}{lcc}
\hline Characteristic & $\begin{array}{c}\text { Downtown } \\
\text { delivery }\end{array}$ & $\begin{array}{c}\text { Suburban } \\
\text { delivery }\end{array}$ \\
\hline Length (km) & 4.4 & 12.1 \\
Duration (min) & 108 & 115 \\
Main phases of delivery & & \\
(\% of total time) & & \\
On foot on level & 28 & 50 \\
surfaces & 9 & 37 \\
By bicycle & 12 & 5 \\
Up stairs & 26 & - \\
Down stairs & & \\
\hline
\end{tabular}


Table 4. Means and standard deviations of the maximal oxygen uptake ( $\mathrm{VO}_{2}$ max), maximal heart rate (HR max) and maximal ventilation ( $\dot{\mathrm{V}}_{\mathrm{E}} \max$ ) of the 12 groups.

\begin{tabular}{|c|c|c|c|c|c|c|c|c|c|}
\hline \multirow{3}{*}{ Group } & \multirow{3}{*}{$\mathrm{n}$} & \multicolumn{4}{|c|}{$\mathrm{VO}_{2} \max$} & \multirow{2}{*}{\multicolumn{2}{|c|}{$\begin{array}{c}\text { HRmax } \\
\text { (beats/min) }\end{array}$}} & \multirow{2}{*}{\multicolumn{2}{|c|}{$\begin{array}{l}\mathrm{V}_{\mathrm{Emax}} \max \\
(1 / \min )\end{array}$}} \\
\hline & & \multicolumn{2}{|c|}{$(1 / \min )$} & \multicolumn{2}{|c|}{$(\mathrm{ml} / \mathrm{kg} \cdot \mathrm{min})$} & & & & \\
\hline & & Mean & $\mathrm{SD}$ & Mean & $\mathrm{SD}$ & Mean & $\mathrm{SD}$ & Mean & $\mathrm{SD}$ \\
\hline \multicolumn{10}{|l|}{ Men $<35$ vears } \\
\hline \multicolumn{10}{|l|}{$<35$ years } \\
\hline Downtown & 5 & 2.80 & 0.42 & 38.9 & 4.1 & 191.6 & 5.2 & 82.0 & 11.0 \\
\hline $\begin{array}{l}\text { Suburban } \\
35-50 \text { years }\end{array}$ & 4 & 3.09 & 0.19 & 44.8 & 4.3 & 193.2 & 11.9 & 92.4 & 10.2 \\
\hline Downtown & 3 & 2.77 & 0.68 & 38.4 & 2.7 & 176.7 & 1.5 & 97.1 & 5.8 \\
\hline Suburban & 4 & 2.99 & 0.41 & 40.1 & 2.8 & 189.5 & 5.4 & 74.6 & 15.3 \\
\hline \multicolumn{10}{|l|}{$>50$ years } \\
\hline Downtown & 5 & 2.36 & 0.37 & 32.1 & 4.5 & 176.0 & 11.8 & 61.5 & 10.2 \\
\hline Suburban & 4 & 2.32 & 0.38 & 31.3 & 7.6 & 156.7 & 13.0 & 17.4 & 11.1 \\
\hline \multicolumn{10}{|l|}{$\begin{array}{l}\text { Women } \\
<35 \text { years }\end{array}$} \\
\hline Downtown & 5 & 1.91 & 0.09 & 33.0 & 2.9 & 189.6 & 6.0 & 55.1 & 7.5 \\
\hline Suburban & 5 & 1.96 & 0.29 & 33.7 & 1.5 & 184.6 & 10.3 & 56.1 & 18.4 \\
\hline $35-50$ years & & & & & & & & & \\
\hline Downtown & 5 & 2.00 & 0.36 & 33.3 & 2.2 & 182.4 & 4.6 & 52.9 & 10.5 \\
\hline $\begin{array}{c}\text { Suburban } \\
>50 \text { years }\end{array}$ & 4 & 2.12 & 0.21 & 31.7 & 3.5 & 180.2 & 10.0 & 63.9 & 12.7 \\
\hline Downtown & 4 & 184 & 0.22 & 30.3 & 1.9 & 168.2 & 7.8 & 59.3 & 13.7 \\
\hline Suburban & 3 & 1.80 & 0.06 & 26.8 & 2.9 & 162.3 & 2.9 & 48.5 & 4.6 \\
\hline
\end{tabular}

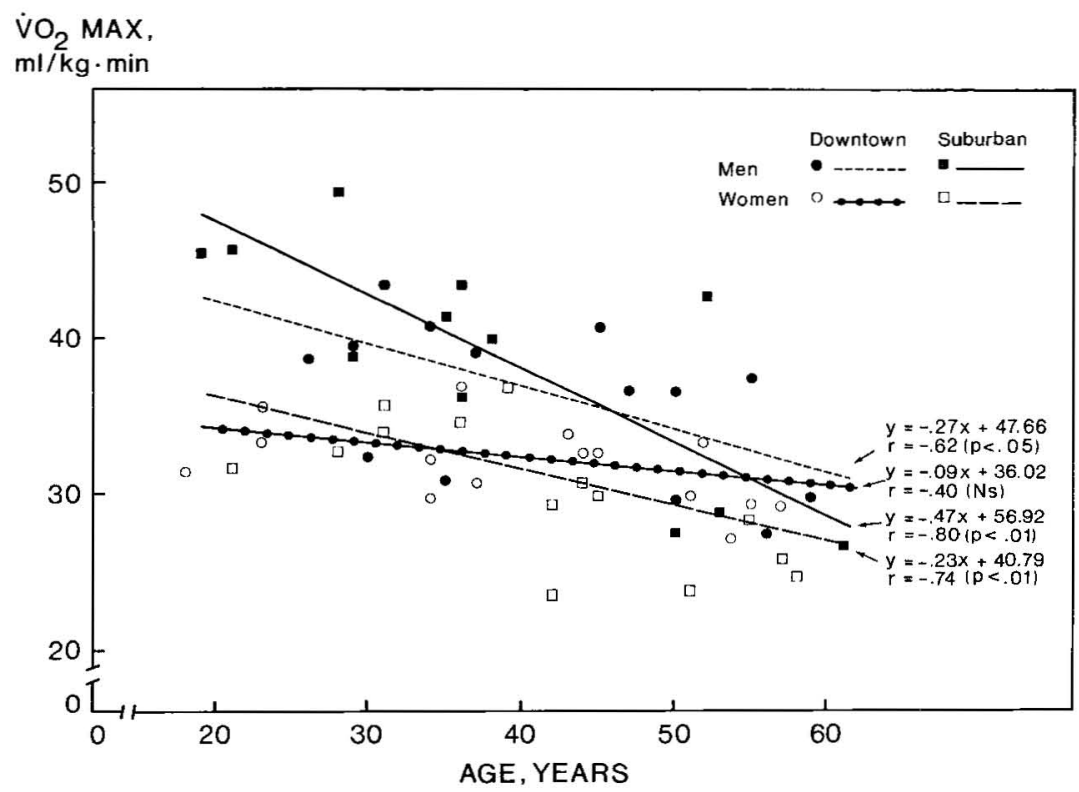

Fig. 1. Decrement in the maximal aerobic power $\left(\mathrm{VO}_{2} \max , \mathrm{ml} / \mathrm{kg} \cdot \min \right)$ of Finnish mail carriers with age. The linear regression lines are shown for both sexes of downtown and suburban carriers.

max with age is illustrated by the linear regression lines in fig. 1 . All the correlation coefficients were statistically significant at the $p$ level of $<0.05$ with the ex- ception of the coefficient of the female downtown carriers.

The analysis of variance revealed a statistically significant overall $\mathrm{F}$ for $\mathrm{VO}_{2}$ max 
Table 5. Means and standard deviations of the maximal oxygen uptake ( $\mathrm{VO}_{2}$ max) of the different age, sex and delivery groups.

\begin{tabular}{|c|c|c|c|c|c|c|c|}
\hline \multirow{3}{*}{ Group } & \multirow{3}{*}{$\mathrm{n}$} & \multicolumn{6}{|c|}{$\mathrm{VO}_{2} \max$} \\
\hline & & \multicolumn{3}{|c|}{$(1 / \mathrm{min})$} & \multicolumn{3}{|c|}{$(\mathrm{ml} / \mathrm{kg} \cdot \mathrm{min})$} \\
\hline & & Mean & SD & $\mathrm{p}(\mathrm{F})^{\mathrm{a}}$ & Mean & $\mathrm{SD}$ & $p(F)^{a}$ \\
\hline Age & & & & $<0.01$ & & & $<0.001$ \\
\hline$<35$ years & 19 & 2.40 & 5.82 & & 37.2 & 5.6 & \\
\hline $35-50$ years & 16 & 2.42 & 5.79 & & 35.6 & 4.4 & \\
\hline$>50$ years & 16 & 2.12 & 3.83 & & 30.5 & 4.7 & \\
\hline Sex & & & & $<0.001$ & & & $<0.001 \mathrm{~b}$ \\
\hline Men & 25 & 2.71 & 0.47 & & 37.4 & 6.3 & \\
\hline Women & 26 & 1.95 & 0.24 & & 31.9 & 3.2 & \\
\hline Type of delivery & & & & NS & & & NS \\
\hline Downtown & 27 & 2.26 & 0.51 & & 34.2 & 4.3 & \\
\hline Suburban & 24 & 2.39 & 0.56 & & 35.0 & 6.9 & \\
\hline
\end{tabular}

a $\mathrm{P}$ values based on the overall $\mathrm{F}$ test in the analysis of variance.

b Nonuniform effect on the two types of delivery.

Table 6. Means and standard deviations of the heart rate (HR) and estimated oxygen consumption $\left(\mathrm{V}_{2}\right)$ of the entire delivery time of the different age, sex and delivery groups.

\begin{tabular}{|c|c|c|c|c|c|c|c|}
\hline \multirow{2}{*}{ Group } & \multirow{2}{*}{$\mathrm{n}$} & \multicolumn{3}{|c|}{$\begin{array}{c}\mathrm{HR} \\
\text { (beats/min) }\end{array}$} & \multicolumn{3}{|c|}{$\begin{array}{c}\mathrm{VO}_{2} \\
(\mathrm{ml} / \mathrm{kg} \cdot \min )\end{array}$} \\
\hline & & Mean & $\mathrm{SD}$ & $\mathrm{p}(\mathrm{F})^{\mathrm{a}}$ & Mean & SD & $p(F)^{a}$ \\
\hline Age & & & & NS & & & NS \\
\hline$<35$ years & 19 & 123.9 & 16.4 & & 19.9 & 4.9 & \\
\hline $35-50$ years & 17 & 122.4 & 15.1 & & 18.4 & 5.0 & \\
\hline$>50$ years & 18 & 112.8 & 15.1 & & 16.5 & 4.2 & \\
\hline Sex & & & & NS & & & NS \\
\hline Men & 26 & 117.1 & 15.4 & & 18.6 & 5.5 & \\
\hline Women & 27 & 122.1 & 16.5 & & 18.0 & 4.1 & \\
\hline Type of delivery & & & & $<0.05$ & & & $<0.05$ \\
\hline Downtown & 28 & 115.5 & 15.6 & & 16.7 & 4.4 & \\
\hline Suburban & 25 & 124.3 & 15.6 & & 20.1 & 4.7 & \\
\hline
\end{tabular}

a $P$ values based on the overall $F$ tests in the analysis of variance.

for age and sex but a nonsignificant $F$ for the type of delivery (table 5). The analysis showed a two-way interaction between sex and type of delivery for the $\mathrm{V}_{2}$ $\max \mathrm{ml} / \mathrm{kg} \cdot \min$ values and indicated that the effect of sex was not uniform among downtown and suburban carriers. The follow-up test between the means of the three age groups yielded significant differences between age groups $>50$ and $<35$ and between $>50$ and $35-50$.

The mean heart rate and the estimated oxygen consumption for the entire delivery time (table 6) was lower in the oldest age group than in the two other age groups, but the difference was not significant. The means of the men and women did not differ from each other in either variable, but were lower in downtown than in suburban delivery $(\mathrm{p}(\mathrm{F})<0.05)$.

The means and standard deviations of the RAS of the entire delivery time, the longest phase of work, and the most straining phase of work are shown in table 7 . The analysis of variance indicated nonsignificant differences between the age groups, but significantly more strain for women than for men, and more strain for suburban delivery than for downtown delivery. These two RAS differences were 
Table 7. Relative aerobic strain of the entire delivery time, longest phase of work and the most straining phase of work for the different age, sex and delivery groups.

\begin{tabular}{|c|c|c|c|c|c|c|c|c|c|c|}
\hline \multirow{2}{*}{ Group } & \multirow{2}{*}{$\mathrm{n}$} & \multicolumn{3}{|c|}{ Entire delivery } & \multicolumn{3}{|c|}{ Longest phase } & \multirow{2}{*}{$\frac{\text { Most }}{\text { ivean }}$} & \multicolumn{2}{|c|}{ straining } \\
\hline & & Mean & $\mathrm{SD}$ & $\mathrm{p}(\mathrm{F})^{\mathrm{a}}$ & Mean & $\mathrm{SD}$ & $\mathrm{p}(\mathrm{F})^{\mathrm{a}}$ & & $\mathrm{SD}$ & $\mathrm{p}(\mathrm{F})^{\mathrm{a}}$ \\
\hline Age & & & & NS & & & NS & & & NS \\
\hline$<35$ years & 19 & 54.0 & 12.4 & & 51.6 & 13.4 & & 68.4 & 10.7 & \\
\hline $35-50$ years & 16 & 51.3 & 13.3 & & 52.0 & 12.9 & & 63.8 & 14.8 & \\
\hline$>50$ years & 16 & 55.4 & 14.8 & & 54.1 & 15.0 & & 68.4 & 17.5 & \\
\hline Sex & & & & $<0.05$ & & & $<0.05$ & & & $<0.05^{b}$ \\
\hline Men & 25 & 49.5 & 12.4 & & 48.7 & 11.8 & & 62.9 & 15.6 & \\
\hline Women & 26 & 57.4 & 13.3 & & $5 \cdot 6.3$ & 14.3 & & 70.9 & 11.8 & \\
\hline $\begin{array}{l}\text { Type of } \\
\text { delivery }\end{array}$ & & & & $<0.05$ & & & $<0.01$ & & & NS \\
\hline Downtown & 27 & 49.5 & 13.1 & & 47.9 & 12.3 & & 66.3 & 14.2 & \\
\hline Suburban & 24 & 58.2 & 12.3 & & 57.8 & 13.2 & & 67.7 & 14.6 & \\
\hline
\end{tabular}

a $P$ values based on the overall $F$ test in the analysis of variance.

b Nonuniform effect on the two types of delivery.

consistent for the entire length of delivery and for the longest single phase of delivery. The results for the most straining phase included a significant three-way interaction. Subsequent testing indicated a nonuniform effect of sex on the two types of delivery.

\section{DISCUSSION}

Theoretical considerations suggest that, when the energy demand of a given work remains constant, the relative physiological strain increases with age and is higher in women than in men due to the differences in work capacity. This study was undertaken to examine whether this hypothesis holds for mail carriers in an occupational situation.

The generally known trends of maximal aerobic power for age and sex were demonstrated well with our data (fig. 2). The decrement in $\mathrm{VO}_{2} \max$ of $0.4 \mathrm{ml} / \mathrm{kg} \cdot \min$ per year for men agrees rather well with annual changes reported for North American and Scandinavian untrained men in cross-sectional studies (8). The corresponding yearly decrement of $0.2 \mathrm{ml} / \mathrm{kg} \cdot \mathrm{min}$ for women was somewhat less than the trend illustrated by the regression line constructed for untrained women from the data compiled by Drinkwater (6).

The mail carriers' work capacity was close to that of Swedish building construc- tion workers (1) but lower than the work capacity of Norwegian lumberjacks (3). When the work strain in mail delivery is considered, it is rather surprising that the work capacity of mail carriers does not differ from the so-called untrained population. This phenomenon may reflect the strong effect of selection which operates among people who voluntarily come to work capacity testing, as is most often the case with so-called untrained people.

The estimated energy consumption of mail delivery was independent of age and sex but higher in suburban than in downtown delivery (table 6). The observed difference between the delivery types was somewhat unexpected, since demanding stairclimbing is generally thought to characterize downtown delivery. However, in our sample, stairclimbing was found to represent only a little more than $10 \%$ of the total delivery time in downtown delivery and almost the same amount (approx. $5 \%$ ) was found in suburban delivery. On the other hand, bicycle riding, which required almost half of the suburban delivery time, was found to be the most demanding phase of the work, together with stairclimbing.

When the observed differences in the aerobic power of men and women is considered on one hand and the equal energy demand of the job on the other, a difference in the relative strain of work should be expected between men and women. The 
results of the RAS measurements verified this assumption. A similar effect was expected for age, but the analysis of variance based on the means of the three age groups did not reveal it. We examined the possible effect of age more closely by performing a linear multiple regression analysis with RAS as the dependent variable and sex (coded as $0=$ female, $1=$ male), delivery type (coded as $0=$ downtown, $1=$ suburban), and age as the independent variables for age groups $>35,>40,>45,>50$. Age had the highest partial correlation coefficient in all age groups. The correlation coefficient between age and RAS was $0.62(p<0.05)$ for the age group of $>50$ years (fig. 3 ). This correlation was not significant when the lower age limit was decreased to 45,40 and 35 years, and thus a dependence between RAS and age was indicated only after the age of 50 .

The mean RAS of mail delivery was found to be $55 \%$ of the maximal aerobic power of the carriers. This level is higher than the work strain of $37 \%$ of Norwegian coastal fisherman (10) and that of $40 \%$ of Swedish building construction workers (1). However, the values are not directly comparable because of the short duration of mail delivery. According to the formula for maximal allowable caloric expenditure for different durations of work devised by Bink et al. (4), the mean measured relative strain exceeded this limit in all age groups of women carriers and notably (by up to $30 \%$ ) among suburban women carriers.

From the occupational health and safety point of view the main results of our study were the higher work strain among women than men and the increasing strain with age after the age of 50 . These differences were obtained in a work situation in which the carriers are essentially free to set their own work pace. Thus it appears that selfcontrol may not be sufficient to protect some groups of workers from straining themselves beyond an acceptable limit. One can speculate that the standards of the delivery performance may be set by the

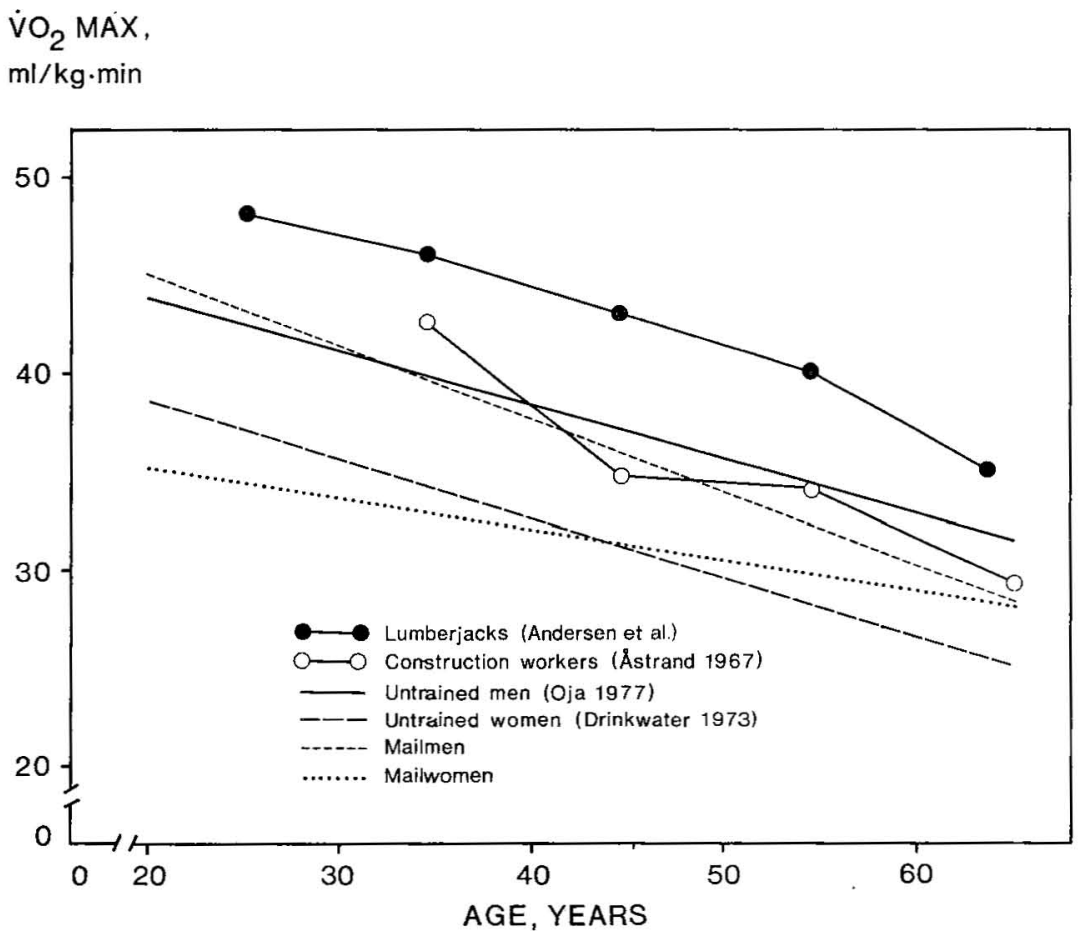

Fig. 2. Comparison of maximal aerobic power ( $\mathrm{VO}_{2} \max , \mathrm{ml} / \mathrm{kg} \cdot \mathrm{min}$ ) of Finnish mail carriers with that of Norwegian lumberjacks, Swedish construction workers and untrained people. 


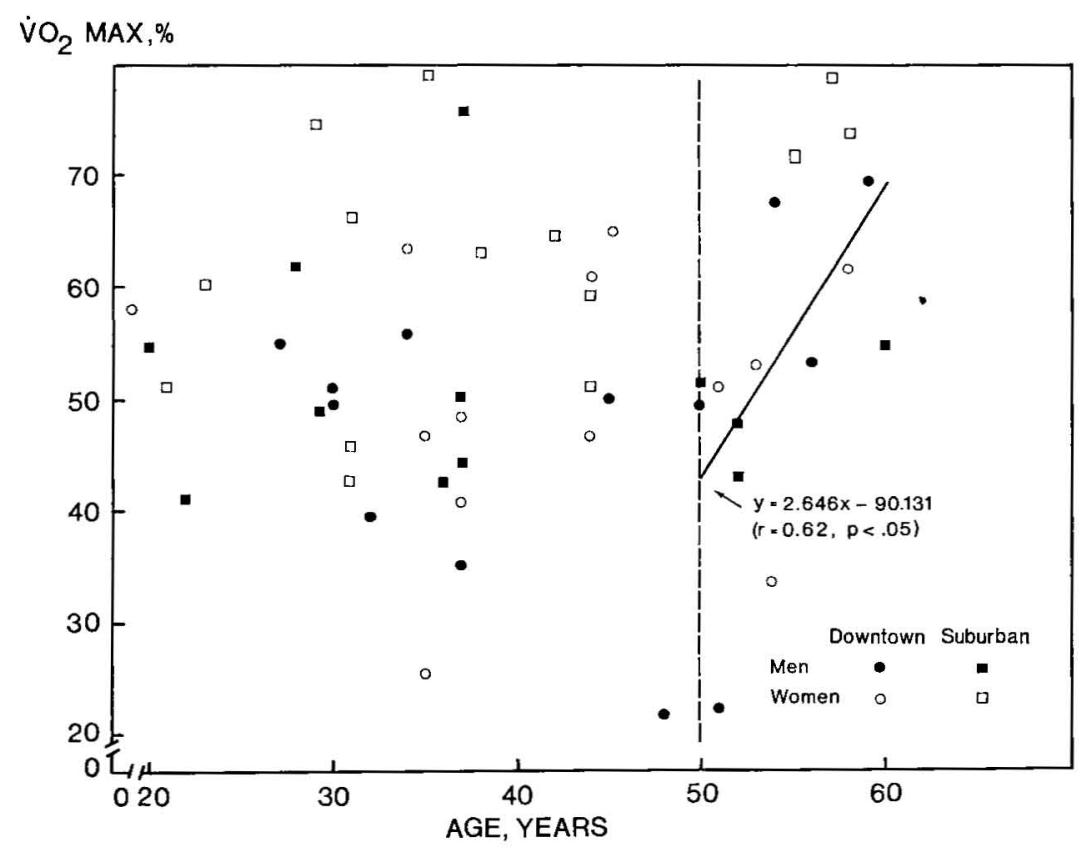

Fig. 3. Plot of relative aerobic strain $\left(\mathrm{VO}_{2} \max , \%\right)$ and age for Finnish mail carriers. The linear regression line is shown for carriers older than 50 years age.

young and fit mailmen and this pressure, together with the time bonus, causes the older and less fit women and older mailmen, in this case, to strain themselves more than they would otherwise.

In summary, we found that the RAS of mail delivery was higher in women than in men and higher in suburban delivery than in downtown delivery. The relative strain of work tended to increase systematically with age after the age of 50 . The measured relative strain of work consistently exceeded the maximal allowable limit among all suburban women carriers, especially among those older than 50 years of age.

On the basis of our results, we conclude that the aerobic strain of mail delivery is high enough to warrant control measures for all mail carriers older than 50 years of age, especially for older women carriers in suburban areas.

\section{ACKNOWLEDGMENTS}

This study was supported financially by Telecommunications.
The authors wish to acknowledge Timo Partanen, M.A., for his statistical consultation.

\section{REFERENCES}

1. ÅSTRAND, I. Degree of strain during building work as related to individual aerobic work capacity. Ergonomics 10 (1967) 293-303.

2. ÁSTRAND, P.-O. and RODAHL, K. Textbook of work physiology. McGraw-Hill Book, New York, N. Y. 1970. 669 p.

3. ANDERSEN, K. L., VIK, T. and SKROBAK-KACZYNSKI, J. Beskrivelse av enkelte biologiske karakteregenskap som har betydning for yrkesytövelsen hos norske skogarbaidere. In: Skogarbeideren og hans arbeidsmiljö (Saertrykk av tidskrift for skogbrok no 2). The Norwegian Forestry Society, Oslo 1976, pp. 22-32.

4. BINK, B., BONJER, F. H. and SLUYS, H. VAN DER. Het physiek arbeidsvermogen ven de mens. $T$ eff. doc. 31 (1961) $526 \mathrm{p}$.

5. ChRistensen, E. H. Physiological evaluation of work in the Nykroppa iron works. In: W. F. FLOYD and T. WELFORD (eds.), Proceedings of ergonomics society symposium on fatigue. Lewis, Lon- 
don 1953 , pp. $93-108$.

6. DRINKWATER, B. L. Physiological responses of women to exercise. In: J. H. WILMORE (ed.), Exercise and sport sciences reviews (vol. 1). Academic press, New York, N.Y. 1973, pp. 125-153.

7. KIRK, R. E. Experimental design for behavioral sciences. Brooks Cole, Belmont, Calif. 1968, p. 91.

8. OJA, P. Iän ja fyysisen aktiivisuuden vaikutus aerobiseen suorituskykyyn suomalai-

Received for publication: 1977-08-25 silla keski-ikäisillä miehillä. Duodecim (In press)

9. PASSMORE, R. and DURNIN, J. V. G. A. Human energy expenditure. Physiol. rev. 35 (1955) $802-840$.

10. ROHDAHL, K., VOKAC, Z., FUGELLI, P., VAAGE, O. and MAEHLUM, S. Circulatory strain, estimated energy output and catecholamine excretion in Norwegian coastal fishermen. Ergonomics 17 (1975) $585-602$. 